\title{
Laryngopharyngeal reflux
}

\author{
Laringofaringeal reflü \\ Ahmet Burak Toros', Sema Zer Toros ${ }^{2}$ \\ ${ }^{1}$ Department of Gastroenterobepatology, Liv Ulus Hospital, Istanbul, Turkey \\ ${ }^{2}$ Department of Otorbinolaryngology, Haydarpaşa Numune Training and Research Hospital, İstanbul, Turkey
}

\begin{abstract}
Gastroesophageal reflux disease is a common medical condition affecting approximately $35 \%-40 \%$ of the adult population in the Western world. Laryngopharyngeal reflux is an extraesophageal variant of gastroesophageal reflux disease that affects the larynx and pharynx. In recent years, many otolaryngologists have acknowledged the existence and potential importance of laryngopharyngeal reflux in patients with otolaryngologic complaints. The exact prevalance of laryngopharyngeal reflux is unknown. However, there is increasing evidence that gastroesophageal reflux disease may cause rhinological and laryngopharyngeal symptoms and at least $10 \%$ of all patients presenting to the otolaryngologists, have symptoms related to gastroesophageal reflux disease. Here we tried to summarize the mainlines of the larynopharyngeal reflux disease and diagnosis-treatment options up to date.
\end{abstract}

Key words: Laryngopharyngeal reflux, gastroesophageal reflux disease.

Symptoms of gastroesophageal reflux are quite common, affecting approximately $35-40 \%$ of the adult population in the Western world. ${ }^{[1,2]}$ Gastroesophageal reflux disease (GERD) is defined as a condition that develops when the reflux of stomach contents causes troublesome symptoms and/or complications. ${ }^{[3]}$ GERD occurs when the esophageal mucosa is bathed in acid-containing secretions. Under normal conditions, several mechanisms exist to minimize esophageal acid exposure. The most important mechanism is the lower esophageal sphincter, which remains closed between swallows, separating the gastric and esophageal compartments. Other factors contributing to esophageal protection include saliva, esophageal bicarbonate secretion and esophageal motility.

\begin{abstract}
Özet
Gastroözefajial reflü hastalığı, Batı dünyasındaki yetişkin nüfusun yaklaşı \% 35-40 kadarını etkileyen bir rahatsızlıktır. Laringofaringeal reflü ise, bunun larinks ve farinksi etkileyen, özefagus dışı bir türevidir. Son yıllarda birçok otorinolaringolojist, yakınması olan hastalarda laringofaringeal reflünün hadiseye katkısını saptayıp tanımladılar. Laringofaringeal reflünün kesin sıklığı bilinmemekle birlikte; kulak burun boğaz polikliniklerine başvuran hastaların \%10'unda altta yatan nedenin bu olduğu düşünülmektedir. Bu çalışmada, laringofaringeal reflünün ana hatlarını tanımlamaya ve günümüzdeki tanı ve tedavi seçeneklerini özetlemeye çalıştık.
\end{abstract}

Anahtar sözcükler: Laringofaringeal reflü, gastroözefajial reflü hastalığı.

Laryngopharyngeal reflux (LPR) is an extraesophageal variant of gastroesophageal reflux disease that affects the larynx and pharynx. In recent years, many otolaryngologists have acknowledged the existence and potential importance of laryngopharyngeal reflux in patients with otolaryngologic complaints. ${ }^{[4]}$ The exact prevalance of LPR is unknown. But there is increasing evidence that GERD may cause rhinological and laryngopharyngeal symptoms and at least $10 \%$ of all patients presenting to the otolaryngologists have symptoms related to GERD..$^{[5]}$

It has been claimed that gastroesophageal reflux disease is associated with pulmonary symptoms and lower airway diseases (asthma, chronic cough, bronchitis, aspiration pneumonia and idiopathic pulmonary fibrosis), otorhino-
Correspondence: Ahmet Burak Toros, MD. Department of Gastroenterohepatology, Liv Ulus Hospital, Istanbul, Turkey.

e-mail: aburaktoros@yahoo.com

Received: July 18, 2013; Accepted: September 26, 2013; Published online: January 29, 2014
Online available at: www.jmedupdates.org doi:10.2399/jmu.2013003009 QR code:

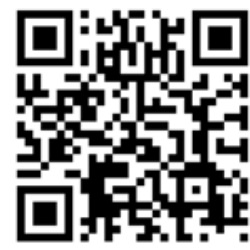


laryngologic symptoms and signs (hoarseness, laryngitis, subglottic stenosis, vocal cord granuloma and laryngeal carcinoma) and other extraesophageal manifestations (noncardiac chest pain, dental erosion, sinusitis, pharyngitis and sleep apnea). ${ }^{[6]}$

\section{Signs and Symptoms}

Classic reflux symptoms (heartburn and regurgitation), which are referred to as "typical gastroesophageal reflux disease," may be absent in more than half the patients presenting with extra-esophageal manifestations. The majority of patients with laryngopharyngeal reflux do not report classical reflux symptoms like heartburn and regurgitation. ${ }^{[7,8]}$

Common signs and symptoms of reflux laryngitis include morning hoarseness, prolonged voice warm-up time (greater than 20 to 30 minutes), halitosis, excessive phlegm, frequent throat clearing, xerostomia (dry mouth), coated tongue, sensation of a lump in the throat (globus sensation), throat tickle, dysphagia, regurgitation of gastric contents, chronic sore throat, possibly geographic tongue, nocturnal cough, chronic or recurrent cough, closing off the airway (laryngospasm), recurrent airway problems in infants. laryngopharyngeal reflux has also been associated with sudden infant death syndrome. ${ }^{[9]}$

Laryngeal abnormalities may be caused by direct injury or by a secondary mechanism. Direct injury is due to contact of acid and pepsin with laryngeal mucosa, resulting in mucosal damage. Frequently, patients present to the otolaryngologists with symptoms such as dry or sore throat, globus sensation, hoarseness, cough, dysphagia, or buccal burning [5]. Because of the variability of otolaryngological symptoms, the exact prevalance is unknown. ${ }^{[10]}$ Chronic laryngeal signs and symptoms associated with gastroesophageal reflux disease are often referred to as reflux laryngitis or laryngopharyngeal reflux. ${ }^{[1]}$

Laryngopharyngeal reflux can lead to chronic otitis media with effusion (OME), which is characterized by the presence of a middle ear effusion in the middle ear space for 3 months or longer. ${ }^{[12]}$ Acid reflux is thought to cause inflammation of the nasopharynx, dysfunction of the Eustachian tube, and impairment of the mucociliary clearance, thus leading to increase in the incidence of $\mathrm{OME}{ }^{[13]}$

\section{Diagnosis}

The $\mathrm{pH}$ impedance testing seems to offer the most objective data to allow accurate diagnosis and help establish causation through the symptom index. It is the current "gold standard," but the accuracy of this measure also has come into question. This examination is subject to variability, including probe placement or movement, intermittent reflux not occurring during the test period, and data interpretation. Pharyngeal probes (versus esophageal probes) have been developed to assess the degree of acid that reaches the pharynx. However, impedance (and acid) probes may be inaccurate when allowed to dry, as may occur in the pharynx, resulting in "pseudoreflux". ${ }^{[14]}$ The yield on hypopharyngeal probes has been demonstrated to be less than $50 \%$ when all artifacts are excluded. ${ }^{[15]}$ Despite this, studies often rely on $\mathrm{pH}$ impedance testing with pharyngeal sensors to diagnose LPR. ${ }^{[16]}$ However, 24-hour monitoring is not always used due to patient resistance, expense, difficulty in interpretation, and equipment availability, making data even more difficult to interpret. $\mathrm{pH}$ monitoring also requires manometry to determine the location of the lower esophageal sphincter. If placement is not accurate, data are not valid. Even a 1-cm discrepancy in placement causes spurious readings. ${ }^{[17]}$ Finally, norms have not been established for $\mathrm{pH}$ in the hypopharynx, although the number of drops below $\mathrm{pH} 4$ and the percentage of time below $\mathrm{pH} 4$ are commonly used parameters.

Laryngeal examination with special emphasis on the posterior location of tissue injury can be helpful for the diagnosis of LPR ${ }^{[18]}$ The severity of mucosal injury may be graded according to the RFS by Belafsky 2001. ${ }^{[19]}$ The RFS is an 8item clinical severity scale based on findings during fiberoptic laryngoscopy. However, this RFS system has been criticized to have high inter- or intra-observer variability and low specificity for reflux laryngitis. ${ }^{[20]}$ Therefore, it is very important to exclude meticulously other potential etiologies that can lead to laryngeal irritation (for example smoking).

The empiric therapy with aggressive acid suppression, usually BID dosing of protonpump inhibitors (PPIs), is currently recommended as the most practical and cost effective approach for the patients suspected with extra-esophageal presentations of GERD. ${ }^{[2]]}$ It must also be kept in mind that LPR is a variant of GERD and esophagogastroduodenoscopy with antral biopsies is the standard diagnostic tool for GERD.

\section{Treatment}

Mainstays of therapy are lifestyle modifications, proton pump inhibitors, $\mathrm{H} 2$ receptor antagonists, over-the-counter antacids, and prokinetic agents. Simple lifestyle measures are elevation of the head of the bed, avoidance of food or liquids 3 hours before bedtime, to keep away from fatty, spicy foods, cigarette, and alcohol. Antacids offer temporary relief of symptoms. Proton pump inhibitors are the most effective treatment for gastroesophageal reflux disease symptoms. ${ }^{[2]}$ 
Eradication therapy of Helicobacter pylori also may be appropriate. A gradually increasing number of patients have been undergoing laparoscopic Nissen fundoplication; which, when successful, treats reflux, rather than just treating acidity. For patients who have symptomatic non-acid reflux (common among voice professionals), as well as those who do not achieve adequate acid suppression even on high doses of proton pump inhibitors; surgical intervention may be a good option. ${ }^{[23]}$

Traditionally, otolaryngologists have managed patients with LPR by a therapeutic trial. If definite improvement in symptoms and signs is noted after treatment with a proton pump inhibitor (PPI), some physicians consider the diagnosis confirmed. For patients who show no response to reflux therapy, some otolaryngologists assume reflux has been ruled out and discontinue the PPI, substituting treatment for allergy or some other conditions. In the absence of studies, this approach is particularly problematic since many patients continue to produce at least some acid despite proton pump inhibitors twice daily, and it has been recognized for many years that some patients with reflux do not respond to proton pump inhibitors and continue to produce normal amounts of acid despite treatment. ${ }^{[2]}$ Other otolaryngologists assume that if the patient has failed a therapeutic trial, the LPR is severe and requires even higher doses of PPI therapy and the addition of other reflux or promotility medications.

It has been argued that without the presence of GERD symptoms, improvement in laryngeal symptoms with PPI is unlikely. Behavioral changes and investigation for alternative causes, such as allergy, pulmonary causes, and sinus problems should be instituted. ${ }^{[25]}$ However, significant data have shown at least partial improvement of laryngitis symptoms and laryngoscopic appearance with PPI treatment and behavioral changes. ${ }^{[26]}$

Of note, it is common for laryngeal reflux findings and symptoms to take longer to resolve than esophageal symptoms. Also, symptoms often improve before clinical findings, which may take six months or longer to reverse. ${ }^{[2]}$ Improvement can be seen not only in symptoms and signs but also in objective assessments, such as acoustic parameters. It is reported that jitter, shimmer, and harmonic-tonoise ratio improved significantly after 1-2 months of treatment. ${ }^{[28]}$

Refractory cases may be particularly challenging. Inadequate medication dosage, resistance to medication, reactivity to non-acid reflux in adequately controlled patients, and misdiagnosis are all potential factors. Pro-motility agents and histamine receptor antagonists can be added.

Conflict of Interest: No conflicts declared.

\section{References}

1. Spechler SJ. Epidemiology and natural history of gastrooesophageal reflux disease. Digestion 1992;51 Suppl 1:24-9.

2. Vaezi MF. Therapy insight: gastroesophageal reflux disease and laryngopharyngeal reflux. Nat Clin Pract Gastroenterol Hepatol 2005;2:595-603.

3. Vakil N, Van Zanten SV, Kahrilas P, Dent J, Jones R; Global Consensus Group. The Montreal definition and classification of gastroesophageal reflux disease: a global evidence-based consensus. Am J Gastroenterol 2006;101:1900-20.

4. Sataloff RT, Castell DO, Katz PO, Sataloff DM. Reflux laryngitis and related disorders, 3rd ed. San Diego: Plural Publishing, Inc.; 2006.

5. Tauber S, Gross M, Issing WJ. Association of laryngopharyngeal symptoms with gastroesophageal reflux disease. Laryngoscope 2002;112:879-86.

6. Gursky RR, Da Rosa ARP, Do Valle E, de Borba MA, Valiati AA. Extraesophageal manifestations of gastroesophageal reflux disease. J Bras Pneumol 2006;32:150-60.

7. Poelmans J, Feenstra L, Demedts I, Rutgeerts P, Tack J. The yield of upper gastrointestinal endoscopy in patients with suspected reflux-related chronic ear, nose, and throat symptoms. Am J Gastroenterol 2004;99:1419-26.

8. Hogan WJ, Shaker R. Supraesophageal complications of gastroesophageal reflux. Dis Mon 2000;46:193-232.

9. Sataloff RT, Hawkshaw MJ, Gupta R. Laryngopharyngeal reflux and voice disorders: an overview on disease mechanisms, treatments, and research advances. Discov Med 2010;10:213-24.

10. Ahmad I, Batch AJ. Acid reflux management: ENT perspective. J Laryngol Otol 2004;118:25-30.

11. Richardson BE, Heywood BM, Sims HS, Stoner J, Leopold DA. Laryngopharyngeal reflux: trends in diagnostic interpretation criteria. Dysphagia 2004;19:248-55.

12. Toros SZ, Toros AB, Özel L, et al. Investigation of gastric pepsinogen in middle ear fluid of children with glue ear. Acta OtoLaryngologica 2010;130:1220-4.

13. Karkos PD, Assimakopoulos D, Issing WJ. Pediatric middle ear infections and gastroesophageal reflux. Int J Pediatr Otorhinolaryngol 2004;68:1489-92.

14. Wiener GJ, Koufman JA, Wu WC, Cooper JB, Richter JE, Castell DO. Chronic hoarseness secondary to gastroesophageal reflux disease: documentation with 24-h ambulatory $\mathrm{pH}$ monitoring. Am J Gastroenterol 1989;84:1503-8.

15. Harrell SP, Koopman J, Woosley S, Wo JM. Exclusion of pH artifacts is essential for hypopharyngeal $\mathrm{pH}$ monitoring. Laryngoscope 2007;117:470-4.

16. Joniau S, Bradshaw A, Esterman A, Carney AS. Reflux and laryngitis: a systematic review. Otolaryngol Head Neck Surg 2007;136: 686-92.

17. Postma GN, Belafsky PC, Aviv JE, Koufman JA. Laryngopharyngeal reflux testing. Ear Nose Throat J 2002;81:14-18.

18. Vaezi MF. Sensitivity and specificity of reflux-attributed laryngeal lesions: experimental and clinical evidence. Am J Med 2003;115 Suppl 3A:97S-104S.

19. Belafsky PC, Postma GN, Koufman JA. The validity and reliability of the reflux finding score (RFS). Laryngoscope 2001;111:1313-7.

20. Hopkins C, Yousaf U, Pedersen M. Acid reflux treatment for hoarseness. Cochrane Database Syst Rev 2006;(1):CD005054. 
21. Farrokhi F, Vaezi MF. Extra-esophageal manifestations of gastroesophageal reflux. Oral Dis 2007;13:349-59.

22. Lowe RC, Wolfe MM. Esophageal disorders. In: Andreoli TE, Carpenter CJC, Griggs CR, Benjamin JI, editors. Andreoli and Carpenter's Cecil essentials of medicine. 7th ed. Philadelphia: Elsevier Saunders; 2007. p. 384-9.

23. Sataloff RT, Castell DO, Katz PO, Sataloff DM. Surgical therapy for gastroesophageal reflux disease. In: Reflux laryngitis and related disorders. 3rd ed. San Diego: Plural Publishing, Inc.; 2006. p. 135-62.

24. Bough ID Jr, Sataloff RT, Castell DO, Hills JR, Gideon RM, Spiegel JR. Gastroesophageal reflux disease resistant to Omeprazole therapy. J Voice 1995;9:205-11.
25. Reichel O, Issing WJ. Impact of different $\mathrm{pH}$ thresholds for 24hour dual probe $\mathrm{pH}$ monitoring in patients with suspected laryngopharyngeal reflux. J Laryngol Otol 2008;122:485-9.

26. Kaltenbach T, Crockett S, Gerson LB. Are lifestyle measures effective in patients with gastroesophageal reflux disease? An evidencebased approach. Arch Intern Med 2006;166:965-71.

27. Belafsky PC, Postma GN, Koufman JA. Laryngopharyngeal reflux symptoms improve before changes in physical findings. Laryngoscope 2001;111:979-81.

28. Jin BJ, Lee YS, Jeong SW, Joeng JH, Lee SH, Tae K. Change of acoustic parameters before and after treatment in laryngopharyngeal reflux patients. Laryngoscope 2008;118:938-41.

This is an open access article distributed under the terms of the Creative Commons Attribution-NonCommercial-NoDerivs 3.0 Unported (CC BYNC-ND3.0) Licence (http://creativecommons.org/licenses/by-nc-nd/3.0/) which permits unrestricted noncommercial use, distribution, and reproduction in any medium, provided the original work is properly cited.

Please cite this article as: Toros AB, Zer Toros S. Laryngopharyngeal reflux. J Med Updates 2013;3(3):150-153. 